\title{
The Anatomy of an Oceanic Flood DEPOSIT
}

By Robert A. Wheatcroft, Jeffry C. Borgeld, Rebecca S. Born, David E. Drake, Elana L. Leithold, Charles A. Nittrouer and Christopher K. Sommerfield

$\mathrm{T}$ HE EPISODIC NATLRE of sedimentation on continental shelves is now widely accepted. Insight obtained in subdisciplines ranging from physical oceanography to seismology suggests that shortduration, large-energy events, such as storms. floods. and tsunamis may transport the majority of sediment on continental shelves. These events often form distinct sedimentary deposits or "event beds." which are subsequently modified by physical and biological processes before their ultimate burial. Hence, the majority of the preserved stratigraphic record of continental shelves may comprise event beds in various stages of alteration (e.g.. Nittrouer and Sternberg. 1981).

Studying modern shelf stratigraphic sequences is therefore akin to "channel surfing," whereby one comes upon various partially completed TV programs and tries to figure out the plot. Because we rarely observe the beginning of an event bed (we lost our TV Guide), we are often faced with significant uncertainties. For example, many diagnostic features of event beds are rapidly altered by physical and biological processes. Hence. the origin of most preserved beds is unclear. Observing an event bed in its initial state and documenting its subsequent evolution allows one to sort out shortlived features from those that are likely to persist, and hence be diagnostic of that particular type of event bed. In addition, the rates and modes of alteration of an event bed are likely to change over time. Formation of an event bed may cause largescale mortality of the shelf benthic fauna, leading

R.A. Wheatcroft, Woods Hole Oceanographic Institution, Woods Hole. MA 02543, USA; J.C. Borgeld. Department of Oceanography, Humboldt State University, Arcata, CA 95521. USA; R.S. Born and E.L. Leithold. Department of Marine, Earth and Atmospheric Sciences. North Carolina State University, Raleigh, NC 27695, USA: D.E. Drake, U.S. Geological Survey. Menlo Park, CA 94025, USA; C.A. Nittrouer and C.K. Sommerfield, Marine Sciences Research Center. State University of New York, Stony Brook. NY 11794. USA. to a significantly depressed bioturbation rate. Similarly, grain-size changes associated with the event bed may lead to increased (or decreased) erosion rates during subsequent storms. Extrapolating the rates and modes of alteration inferred from partially altered beds back to the period immediately following an event may lead to serious errors due to such time-dependent effects.

During January 1995, an event bed was formed on the Eel continental shelf by a flood having approximately a 30-y recurrence interval. This event was followed by a smaller, yet still geologically significant. flood in March 1995. Members of the STRATAFORM Seabed Processes Group, of which we represent the shelf component, have conducted extensive coring cruises on the Eel margin during February. May, and September 1995. as well as March and July 1996. During those cruises, we have collected $>300$ box cores on the shelf that have provided a unique view of the initial characteristics of an oceanic flood deposit and its subsequent (and ongoing) physical and biological alteration. Our objectives in this article are to describe the initial characteristics of the flood deposit gleaned from a preliminary analysis of the February and May 1995 samples, and outline continuing and future areas of investigation.

\section{A Flood Dominated Shelf?}

The Eel shelf, as defined by Borgeld (1985), extends for $\sim 70 \mathrm{~km}$ from Cape Mendocino northward to Trinidad Head. Sediment delivery to the margin is dominated by two rivers: the Eel (in the south) and the Mad (in the north). Both of these rivers drain mountainous terrain in the northern California coast range and have exceptional sediment yields when normalized by basin area (i.e., tons $\mathrm{km}^{-2} \mathrm{y}^{-1}$ ) (Brown and Ritter, 1971: Griggs and Hein. 1980: Milliman and Syvitski, 1992). Their combined average annual suspended-sediment load is $\sim 2.6 \times 10^{7}$ metric tons, with the Eel River accounting for $\sim 90 \%$ of the total (Brown and Ritter, 1971). The vast majority of the sediment in these river systems is transported in short-duration discharge events 
during the winter storm season (December-March). Because both rivers have very small flood plains and virtually no estuaries, especially during highdischarge events, the majority of the suspended-sediment load is transported directly into the Pacific Ocean (e.g., Wheatcroft et al., 1997).

Since 1910 the U.S. Geological Survey has maintained a stream-gauging station near the town of Scotia, $26 \mathrm{~km}$ from the Eel River mouth. The discharge record from Scotia indicates that before 1995 there have been five floods with peak discharges $>8,500 \mathrm{~m}^{3} \mathrm{~s}^{-1}$. Floods of this magnitude are capable of transporting $>1.5 \times 10^{7}$ metric tons of sediment or $\sim 60 \%$ of the long-term annual load. The largest of these floods occurred in December 1964, when an estimated $1.4 \times 10^{\circ}$ metric tons of sediment were delivered to the ocean (Brown and Ritter, 1971). It was therefore of little surprise that, when one of us began coring on the Eel margin in the late 1970 's, there was evidence for flood deposits in the shelf sediments (Borgeld, 1985). Subsequent work on the Plio-Pleistocene Rio Dell Formation, an ancient analogue of the Eel margin, indicated that paleoflood deposits could be preserved in the stratigraphic record (Leithold, 1989). Thus, the stratigraphy of the Eel shelf may be dominated by flood deposits, despite the fact that the shelf is subject to several large storms each year.

What had not been done in these earlier studies was to comprehensively document the initial characteristics of a flood deposit and track its subsequent physical and biological evolution. Doing so would require a well-timed flood and a substantial followup effort. In the winter of 1995, we were fortunate to have significant flooding in the Eel River basin, during early and late January, as well as March. The suspended-sediment load and short-term dispersal of the early-January event, the most important of the three, has been discussed in detail by Wheateroft $e t$ al. (1997). In brief, they made estimates of the mass of suspended-sediment load delivered during the flood and the mass of sediment in a layer on the adjacent continental shelf, which showed that only $25 \%$ of the flood sediment could be accounted for in the deposit. In the following, we discuss the smallscale properties of the winter 1995 flood deposits, as well as the initial state and short-term evolution of various shelf-wide sedimentologic features.

\section{Small-Scale Features of the 1995 Flood Deposits}

Cores collected on the shelf in both February and May contained, in places, a well-defined layer on the sediment surface. Distinctive features of the layer included its light tan color relative to typical olive-gray shelf sediments, an abundance of woody material (e.g., conifer needles, leaves, grass), high $(80-90 \%)$ and fairly constant near-surface porosity (Fig. 1A), and a lack of epibenthic macrofauna. The layer also had a higher percentage of clay (Fig. $1 B$ ) and a slightly reduced sand fraction compared

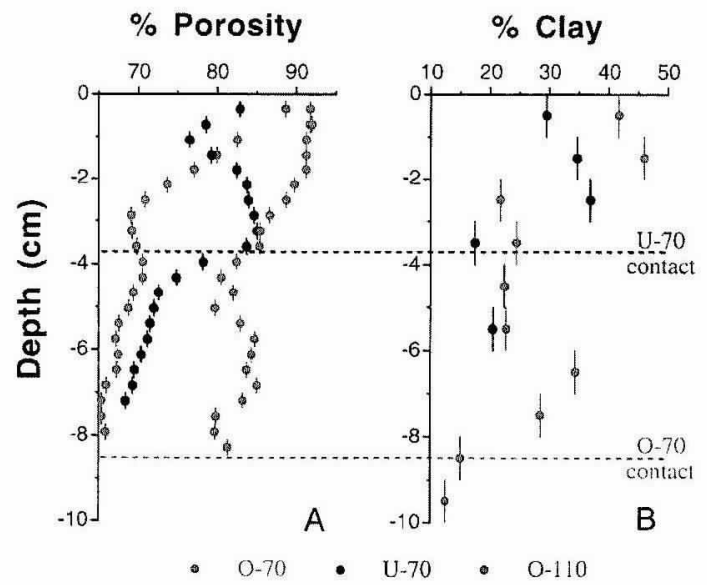

Fig. 1: Vertical profiles of percent porosity and clay from representative stations on the Eel shelf. (A) Porosity was measured using a micro-resistivity probe calibrated with shelf sediments. At stations $0-70$ and $U-70$ porosity was typically $>80 \%$ within the flood deposit (the lower contact of which is denoted by labeled, color-coded dashed lines) and decreased abruptly by $\sim 15 \%(U-70)$ to values of $\sim 70 \%$ in underlying sediments. A porosity profile (station 0-110) typical of non-flood-deposit Eel shelf sediments (i.e., rapidly decreasing in the upper 2-3 cm) is shown for comparison. (B) Vertical profiles of grain size, here represented as $\%$ clay, also show a change between flood and nonflood sediments, with 10-20\% more clay in the flood deposit. Vertical bars in each panel represent the depth interval of the measurement.

with the underlying sediment. Core $\mathrm{x}$-radiographs (Fig. 2) indicate that the layer was up to $8.5 \mathrm{~cm}$ thick, had very few biogenic sedimentary structures and little cross-bedding. Parallel bedding within the thickest part of the layer suggests it was deposited in several pulses (Fig. 2B). The flood layer had a very sharp lower contact, except at the inshore boundary ( $\sim 50 \mathrm{~m}$ water depth), where it was interbedded with the nearshore sands (Fig. 2A).

The layer also had a distinctive radioisotopic signature relative to typical shelf deposits, as well as underlying sediment. In particular, the layer was enriched in the short-lived (half life $=53.3 \mathrm{~d}$ ) radionuclide, ${ }^{7} \mathrm{Be}$. Sediment within the layer contained specific activities in the range of $1-10 \mathrm{dpm} \mathrm{g}^{-1}$, whereas sediment below the layer had no measurable ${ }^{~} \mathrm{Be}$ (Fig. 3A). Profiles of the longer-lived (half life = $22.3 \mathrm{y}$ ) radionuclide, ${ }^{210} \mathrm{~Pb}$, also were unusual. In this case, instead of enrichment, the layer had lower ${ }^{210} \mathrm{~Pb}$ activities than the subjacent sediment (Fig. 3B).

Both of these radioisotopic signatures are consistent with a flood origin for the layer. In general, ${ }^{\mathrm{B}} \mathrm{Be}$ is a good tracer of flood-event deposition because of the positive correlation between seasonal precipitation and atmospheric 'Be fluxes (Young and Silker, 1974; Wallbrink and Murray, 1996), as well as because it has an affinity for particles (Olsen $e t$
. . . the Eel shelf

may be dominated by

flood deposits, de-

spite . . several

large storms each

year. 


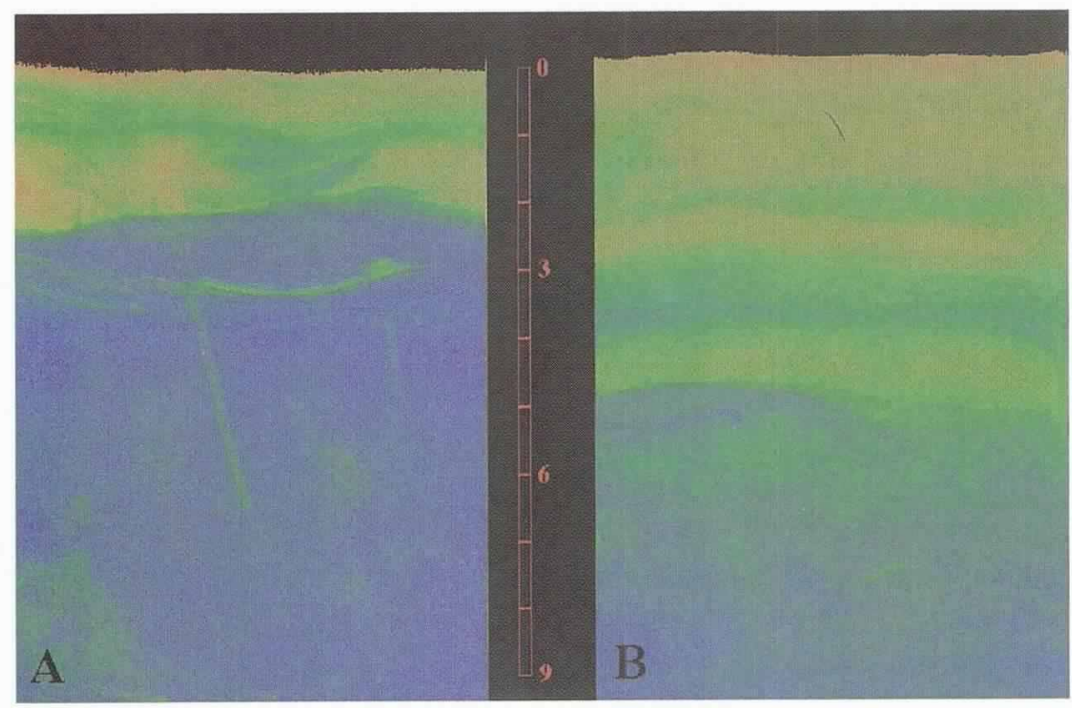

Fig. 2: Representative $x$-radiographs from the Eel shelf. Each radiograph is a pseudo-color image obtained by digitizing a conventional x-radiograph. Orange and green represent relatively low-density sediments, whereas blue represents high-density sediment. (A) Station $K-50$, located $\sim 11 \mathrm{~km}$ north of the Eel River mouth at $50 \mathrm{~m}$, is a sand overlain by $2 \mathrm{~cm}$ of fine-grained flood layer. There is some evidence for wave reworking of both the uppermost portion of the sand and the flood layer. (B) Station S-60, located $\sim 25$ $\mathrm{km}$ north of the river mouth at $60 \mathrm{~m}$, is a sandy-mud overlain by $\sim 5 \mathrm{~cm}$ of fine-grained flood deposit. Station $S-60$ is the site of the intensive bottomboundary-layer measurements discussed by Wiberg et al. (1996, this issue).

\section{The January flood}

deposit extended for

$\sim 30 \mathrm{~km}$ along-shelf

and $8 \mathrm{~km}$ across-

shelf. . .

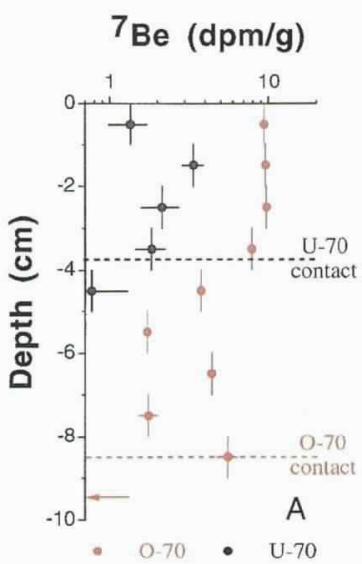

\section{$210 \mathrm{~Pb}(\mathrm{dpm} / \mathrm{g})$}

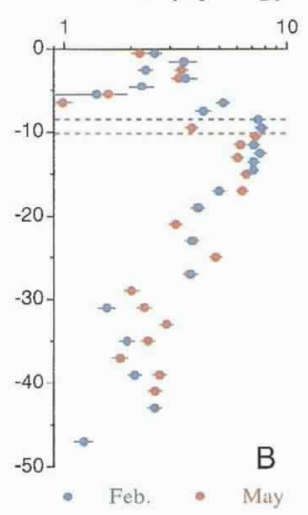

Fig. 3: Vertical profiles of ${ }^{7} \mathrm{Be}$ and ${ }^{210} \mathrm{~Pb}$ from representative stations on the Eel shelf. Specific activities of both radionuclides were determined by $\gamma$-counting 50-70 g of dry sediment. (A) ${ }^{7} \mathrm{Be}$ was present within the flood deposit (the lower contact of which is denoted by labeled, colorcoded dashed lines) at stations $0-70$ and U-70, but was not present in subjacent sediments (the red arrow pointing to the $\mathrm{y}$-axis indicates the sample was counted, but that it did not contain $\left.{ }^{7} \mathrm{Be}\right)$. (B) Conversely, ${ }^{210} \mathrm{~Pb}$ activities measured at station $0-70$ in February and May were relatively low within the deposit, reached a maximum in sediments immediately below the deposit, and then decreased with depth. al., 1986). In the Eel River dispersal system, during periods of high discharge, the terrestrial and marine ${ }^{7} \mathrm{Be}$ inventories are transferred to shelf (and slope) deposits, because the residence time of ${ }^{7} \mathrm{Be}$-labeled particles in river and shelf waters is short relative to radioactive decay. Subsequent sampling of the flood layer during 1995 revealed that February ${ }^{7} \mathrm{Be}$ activities decayed to extinction by September (dry season).

Conversely, the low ${ }^{210} \mathrm{~Pb}$ activities measured in the flood layer, relative to ambient deposits, are a result of rapid deposition of fine-grained subaqueous river-bed and channel-bank sediments, which typically have low specific ${ }^{210} \mathrm{~Pb}$ activities. Subsequent physical and biological mixing of higher-activity particles supported by the marine scavenging regime could potentially increase the ${ }^{210} \mathrm{~Pb}$ inventory of the layer. In contrast to the short-lived ${ }^{7} \mathrm{Be}$ signature, the ${ }^{210} \mathrm{~Pb}$ flood signature may be preserved for decades in the recent sedimentary record. For example at station O-70, a local minimum in the ${ }^{210} \mathrm{~Pb}$ profile at $\sim 30 \mathrm{~cm}$ below the surface (Fig. 3B) occurs in a zone of bedded sediment (from $\mathrm{x}$-radiographs) that may correspond to an earlier flood deposit (1964 flood?).

\section{Large-Scale Features of the 1995 Flood Deposits}

The January flood deposit extended for $\sim 30 \mathrm{~km}$ along-shelf and $8 \mathrm{~km}$ across-shelf and was found entirely north of the Eel River mouth (Fig. 4A). Centered on the 70-m isobath, the layer's inshore boundary was at $\sim 50-\mathrm{m}$ water depth, whereas the offshore boundary occurred at a depth of $\sim 90 \mathrm{~m}$. The deposit's center of mass was located $\sim 18 \mathrm{~km}$ from the river mouth, which is consistent with silt-size particle settling velocities $\left(\sim 0.05 \mathrm{~cm} \mathrm{~s}^{-1}\right)$ and likely alongshelf current speeds $\left(\sim 10 \mathrm{~cm} \mathrm{~s}^{-1}\right)$. In cross section, the thickness of the flood layer was quasi-symmetrical in the across-shelf direction, whereas it was skewed to the north in the along-shelf direction, with an abrupt upstream (i.e., southern) edge (Fig. 5A). By May 1995, the flood deposits extended farther northward along the shelf (Fig. 5A) and into deeper water (to $100 \mathrm{~m}$ ). This change may reflect the initial distribution of sediment discharged to the shelf during the March 1995 flood event and/or it may also represent storm-induced redistribution of the January and March deposits.

The large-scale spatial distribution of surficial $(0-0.5 \mathrm{~cm})$ sediment grain size measured in February (Fig. 4B) was fairly consistent with the thickness data. Surficial grain size was finest ( $>90 \%$ less than $20 \mu \mathrm{m}$ ) within the center of the deposit and coarsened toward the edges. In contrast to the thickness data, the grain-size pattern was symmetrical in the along-shelf direction (Fig. 5B) but skewed toward finer sizes in the offshore direction. Sampling in May revealed a significantly different grain-size pattern on the shelf, in which there was a widespread coarsening of the surface layer. For example, at those stations along the 

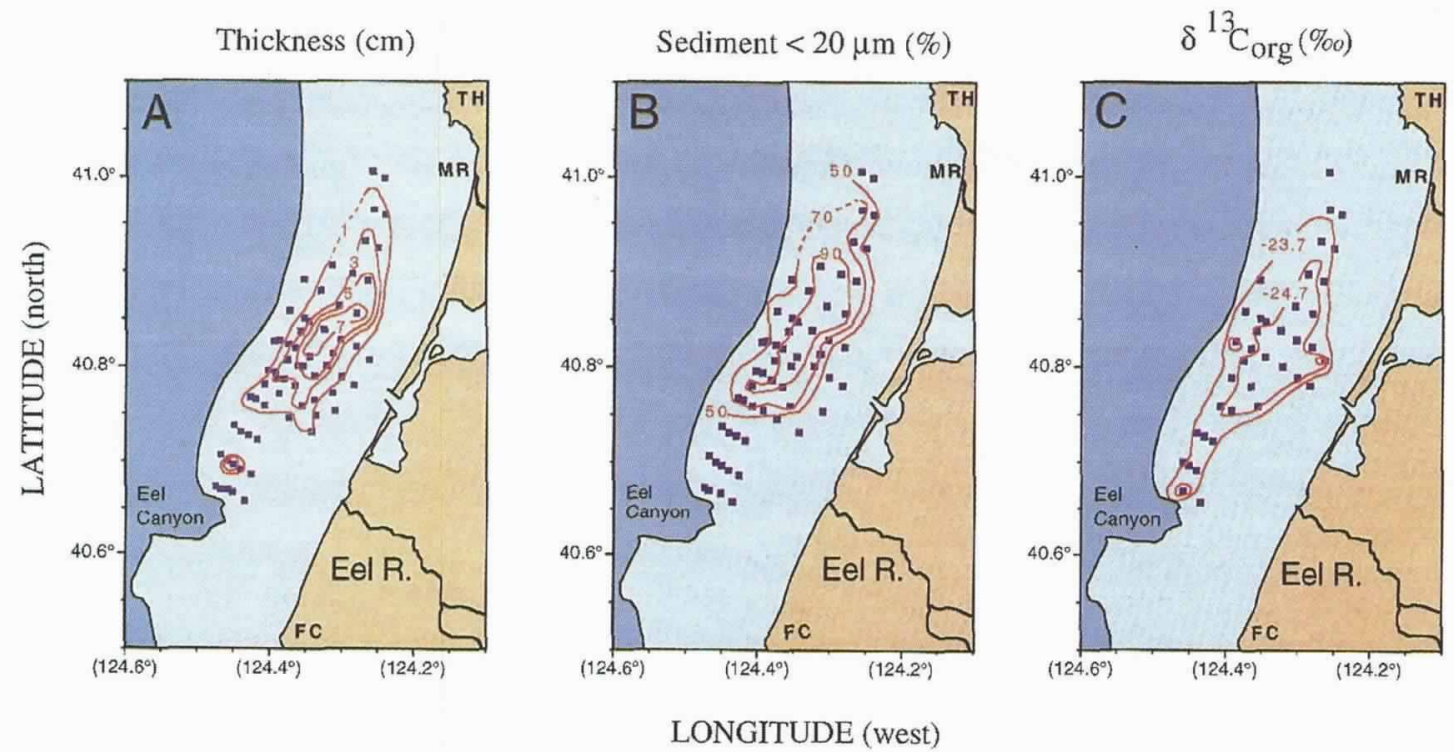

LONGITUDE (west)

Fig. 4: Large-scale distribution of flood-deposit thickness $(\boldsymbol{A})$, surficial grain size $(\boldsymbol{B})$, and $\delta^{13} C_{\text {org }}(\boldsymbol{C})$ on the Eel margin in February 1995. Sample locations are denoted by blue squares. Contour intervals shown in red are in $2 \mathrm{~cm}(\boldsymbol{A}), 20 \%(\boldsymbol{B})$, and 1\%o (C). FC, False Cape; MR, Mad River; TH, Trinidad Head. Water depths greater than $150 \mathrm{~m}$ are denoted by dark blue.

70-m isobath that were finest in February (i.e., $>90 \%$ less than $20 \mu \mathrm{m}$ ), there was a $10-30 \%$ decrease in the $<20 \mu \mathrm{m}$ fraction (Fig. 5B). The reason for this coarsening is unclear, but probably reflects a combination
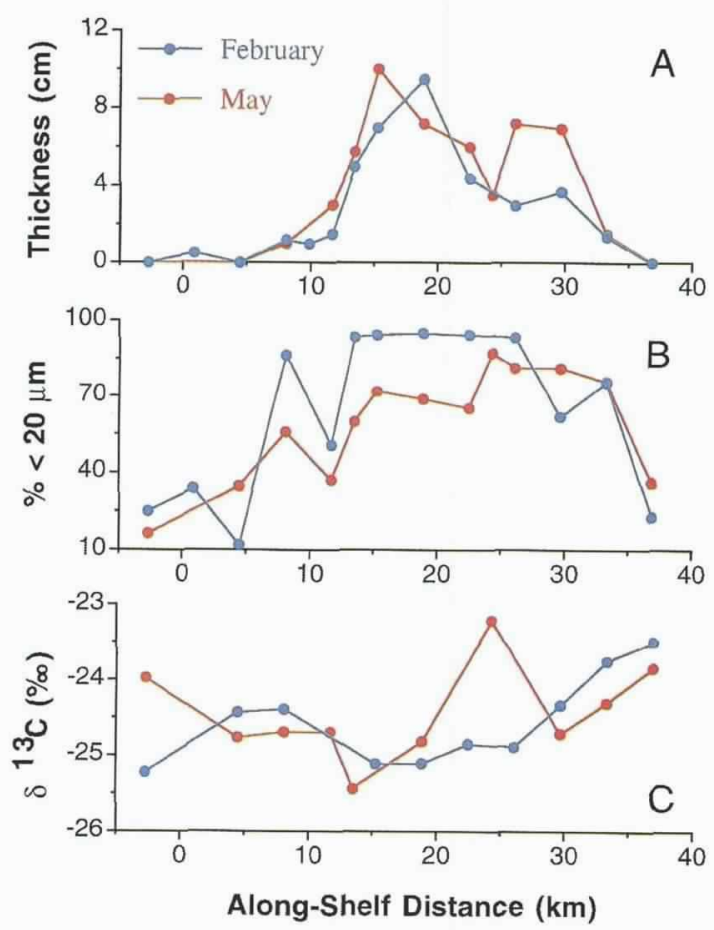

Fig. 5: Temporal and spatial patterns in flood-deposit thickness $(\boldsymbol{A})$, surficial grain size $(\boldsymbol{B})$, and $\delta$ ${ }^{13} C_{\text {org }}(\boldsymbol{C})$ along the 70-m isobath. Distances are measured orthogonal (positive is $031^{\circ} \mathrm{T}$ ) from a line drawn perpendicular offshore of the Eel River mouth. of winnowing and emplacement of coarser sediment eroded from the nearshore during storms.

Stable isotope $\left({ }^{13} \mathrm{C}\right)$ measurements made on the February samples were also broadly consistent with the thickness data (Fig. 4C). The $\delta^{13} \mathrm{C}$ values of organic matter in the center of the flood deposit were isotopically lighter (approximately $-25 \%$ o relative to the PDB standard), whereas sediments on the fringes of the deposit had heavier $\delta{ }^{13} \mathrm{C}_{\text {org }}$ values ( -23 to $-24 \%$ o). This pattern apparently reflects the terrestrial source of the organic carbon in the flood deposit. Suspended-sediment samples taken from the Eel River during January 1995, for example, had a $\delta$ ${ }^{13} \mathrm{C}_{\text {org }}$ value of $-25.2 \%$. The broad-scale $\delta{ }^{13} \mathrm{C}_{\text {org }}$ pattern persisted into May (Fig. 5C), although one anomalously heavy value suggests the influence of physical or biological reworking of the flood deposit.

\section{Future Research}

The creation of a large flood deposit during the initial phase of STRATAFORM has provided us with an unparalleled opportunity to better understand both the formation and alteration of an oceanic event bed. Preliminary findings of the Seabed Processes Group include: 1) a major discrepancy between the mass of fine-grained sediment delivered to the ocean during the floods $\left(\sim 2.5 \times 10^{7}\right.$ metric tons $)$ and the mass found in the flood deposit ( $6 \times 10^{6}$ metric tons), which suggests the Eel River dispersal system is highly dispersive on short time scales (Wheatcroft $e t$ al., 1997); 2) a clear radioisotopic ( $\mathrm{Be}$ and ${ }^{210} \mathrm{~Pb}$ ) and stable isotopic $\left({ }^{13} \mathrm{C}_{\text {org }}\right)$ signature of the flood deposit that may, in the case of ${ }^{210} \mathrm{~Pb}$ and $\delta{ }^{13} \mathrm{C}_{\text {org }}$, facilitate identification of previous flood deposits; and 3) evidence for a progressive winnowing of fine-grained
The creation of a

large flood deposit

... has provided us

with an unparalleled

opportunity . . . 
. . . key questions

pertaining to the in-

fluence of oceanic,

climatic, and tectonic

forcings on shelf

sediments will be ex-

plored. sediment from the deposit during episodes of wave resuspension at water depths of $70-90 \mathrm{~m}$. As much as we have learned, however. there are many more issues that require future investigation.

In particular, it is unclear how key dynamical properties (e.g.. surficial grain size, porosity or yield strength, and bed roughness) of the flood layer will evolve in the near term. Will winnowing continue, resulting eventually in a coarse. erosionresistant layer at the sediment surface, or will bioturbation continually replenish fine particles from deeper within the seabed? Similarly, how will the porosity of the flood deposit evolve over time as the benthic community recovers? Documenting and understanding changes in bed properties on multiple spatial scales will be crucial for interpreting benthic-boundary-layer measurements (e.g., Wiberg et al., 1996, this issue), as well as for building the next generation of sediment transport models. There are other ways in which the flood deposit will change that, although they may not have significance for sediment dynamics, are no less important. For example, determining the modes and rates that the ${ }^{13} \mathrm{C}_{\text {org }}$ and ${ }^{21} \mathrm{~Pb}$ signatures of the flood deposit recover to "typical" oceanic values will provide general insight into the systematics of these two common tracers. Because bioturbation plays a key role in controlling both the small- and largescale geometry of the flood deposit, ongoing studies measuring the temporal and spatial variability in mixing intensity will continue.

Our future plans also include much greater emphasis on older (i.e., $10^{2}$ to $10^{4} \mathrm{y}$ ) sedimentary deposits on the Eel shelf. Evidence of past floods (e.g.. the 1964 event) and major storms are likely to be recorded in the shelf sediments. The frequency of these event beds, as well as the small- and largescale properties of the deposits will be addressed through an extensive kasten and piston coring campaign during the next biennium. Once a better understanding of the space-time variability of the shelf stratigraphy is obtained. then key questions pertaining to the influence of oceanic, climatic, and tectonic forcings on shelf sediments will be explored. At that point, the "plot" of oceanic flood deposits in particu- lar, and shelf strata in general, should be much clearer.

\section{Acknowledgements}

The authors thank the many support personnel and students, especially undergraduate volunteers from Humboldt State University, who have helped with the field and laboratory portions of this research. Funding was provided by the Geology and Geophysics Program of the Office of Naval Research. This article is contribution 9271 from the Woods Hole Oceanographic Institution.

\section{References}

Borgeld, J.C.. 1985: Holocene stratigraphy and sedimentation on the northern California continental shelf. Ph.D. the sis. University of Washington. $177 \mathrm{pp}$.

Brown. W.M. and J.R. Rittes, 1971: Sediment transport and turbidity in the Eel River Basin. Califomia. U.S. Geological Survey Water-Supply Paper 1986, $70 \mathrm{pp}$.

Griggs, G.B, and J.R. Hein, 1980: Sources, dispersal, and clay mineral composition of tine-grained sediment off central and northern California, I. Geol., 8,9, 541-566.

Leithold, E.L., 1989: Depositional processes on an ancient and modern muddy shelf, northern California. Sedimentology, 36. 179-202

Milliman. J.D. and J.P.M. Syvitski. 1992: Geomorphic/tectonic control of sediment discharge to the occan: the importance of small mountainous rivers. $J$. Geol. . $/ 00$. 525-544.

Nittrouer, C.A. and R.W. Sternberg, 1981: The tormation of sedimentary strata in an allochthonous shelf environment: The Washington continental shelt. Mar: Gerll., 42, 201-232.

Olsen. C.R., I.L. Larsen, P.D. Lowry and N.H. Cutshall. 1986: Geochemistry and deposition of $\mathrm{Be}$ in river-estuarine and coastal waters. J. Geophr. Res., 9/, 896-908.

Wallbrink, P.J. and A.S. Murray, 1996: Distribution and variability of 'Be in soils under different surfice cover conditions and its potential for describing soil redistribution processes. Water Resources Res., 32, 467-476.

Wheatcroft, R.A., C.K. Sommertield, D.E. Drake, J.C. Borgeld and C.A. Nittrouer, 1997: Rapid and widespread dispersal of flood sediment on the northern California margin. Geology, Vol. 25. In press.

Wiberg, P.L.. D.A. Cacchione, R.W. Sternberg and L.D Wright. 1996: Linking sediment transport and stratigraphy on the continental shelf. Oceanography, 9. $153-157$.

Young, J.A. and W.B. Silker, 1974: The determination of airsea exchange and oceanic mixing rates using $\mathrm{Be}$ during the Bomex experiment. J. Geophys. Res., 79. 44814489. ] 